\title{
Mercury Content in Upper Layers of Soils from the Areas with Various Impacts of Anthropogenic Pressure
}

\author{
Marcin J. Małuszyński ${ }^{1 *}$, Piotr Dąbrowski', llona Małuszyńska' \\ ${ }^{1}$ Warsaw University of Life Sciences - SGGW, Faculty of Civil and Environmental Engineering, ul. \\ Nowoursynowska 159, 02-776 Warsaw, Poland \\ * Corresponding author's e-mail: marcin_maluszynski@sggw.pl
}

\begin{abstract}
The aim of the conducted research was to determine the mercury content in the upper layers of soil taken from the areas with various impact of anthropogenic pressure. The article presents the content of mercury in the top layers of soils from selected areas of two districts of Warsaw, ie Ursynów and Mokotów. These areas are heavily influenced by the human activity. For comparison, a soil sample was also taken from the area of the Solska Forest, which is an example of an area with a negligible impact of anthropogenic pressure. The mercury content in the analyzed soil samples taken from the area of Warsaw ranged from $0.0334 \mathrm{mg} \cdot \mathrm{kg}^{-1}$ to $0.4004 \mathrm{mg} \cdot \mathrm{kg}^{-1}$ in Ursynów, while the soils from the Mokotów area contained from $0.2320 \mathrm{mg} \cdot \mathrm{kg}^{-1}$ to $1.3098 \mathrm{mg} \cdot \mathrm{kg}^{-1}$. For comparison, the sample from the Solska Forest area contained $0.2544 \mathrm{mg} \mathrm{Hg} \cdot \mathrm{kg}^{-1}$. In order to avoid uncontrolled re-emission and, as a consequence, possible accumulation of this element in the environment, it is necessary to continue monitoring the level of mercury pollution, among others, in soil.
\end{abstract}

Keywords: mercury, anthropopressure, soil

\section{INTRODUCTION}

Mercury is one of the toxic elements negatively affect the quality of the soil environment in areas with different impacts of anthropogenic pressure when emitted into the environment (Hammond, 2005).

The presence of mercury in the soil environment is associated with the presence of this metal in the lithosphere, as well as with human activity. Despite the fact that mercury is present in very small amounts, it can pose a threat to animal and human organisms (Małuszyńska, Popenda, Małuszyński 2011, Bartkowiak, Jaworska, Różański, 2013).

The recent studies of $\mathrm{Xu}$ et al. (2015) confirm the increasing $\mathrm{Hg}$ concentration in soil by the factor of 3 to 10 indicating combustion of fossil fuels together with long-range atmospheric processes of transport are regarded as the main source of pollution. This poses a serious threat to animals and humans because $\mathrm{Hg}$ passing through environmental compartments can be deposited and re-emitted many times.
The aim of the conducted research was to determine the mercury content in the upper layers of soil taken from areas with various impacts of anthropogenic pressure.

\section{MATERIALS AND METHODS}

The soil samples were taken from the surface layer of soil $(0-20 \mathrm{~cm})$ from selected areas of two districts of Warsaw, i.e. from Ursynów and Mokotów. These areas are significantly influenced by human activities. For comparison, a soil sample was also taken from the area of the Solska Forest, which is an example of an area with a slight impact of anthropogenic pressure. Nineteen square surfaces and dimensions of $1.5 \times 1.5 \mathrm{~m}$ were selected in the study areas. Five samples were taken from each square, which were homogenised and averaged to $1 \mathrm{~kg}$ of sample for the analysis of soil properties and mercury content. 
The studied material was initially prepared by removing plants, stones and visible invertebrate parts for further analytical steps. Then, the samples were dried under the room temperature within five weeks in order to obtain air stable dry mass. Afterwards, the granulometeric composition and other physicochemical soil properties were determined according to known soil procedures [Ostrowska et al. 1991]: $\mathrm{pH}$ in $1 \mathrm{~mol} \cdot \mathrm{dm}^{-3}$ $\mathrm{KCl}$ - potentiometric method using $\mathrm{pH}$-meter with glass combine electrode, hydrolytic acidity (Hh) - Kappen's method, sum of alkalinity exchangeable cations (S) - Kappen's method, cation exchange capacity of soil (T) - sum of hydrolytic acidity and sum of alkalinity exchangeable cations, organic matter content (OM) by losing mass during anneal.

The concentration of the total mercury in this study was determined using the atomic absorption spectroscopy (ASA) method, and the analysis was performed on an AMA 254 mercury analyzer (Altec, Czech Republic). The analyzer used allows the determination of mercury in biological samples (both fresh and dried to a constant mass) and environmental tests, without the necessity of their earlier mineralization in acids, under the conditions of high temperature and pressure.

For the analysis, 100 to $300 \mathrm{mg}$ of sample were taken, which was placed in a nickel cuvette, where it was automatically weighed and dried. The sample was then subjected to thermal decomposition in the oxygen stream to the gaseous form, and its decomposition products were transferred to the amalgamator for the selective capture of mercury. Mercury in the form of steam is released from the amalgamator by its short heating. The amount of mercury released was measured with the atomic absorption method (the detector in the AMA 254 analyzer is a silicon UV diode) at a wavelength of $254 \mathrm{~nm}$, in a system of two measuring cells. The samples were analyzed at specific cycle parameters: $60 / 160 / 60$, which in turn means the times (in seconds) of drying, decomposition (at $550^{\circ} \mathrm{C}$ ) and waiting for the measurement. The mercury detection limit for this apparatus is $0.01 \mathrm{ng}$. For each sample, 2 replicates were made and the obtained mean concentration result was given in $\mathrm{mg} \cdot \mathrm{kg}^{-1}$ of dry matter.

During the determination of the mercury content in soils Certified Reference Standard EnviroMAT Contaminated Soil (SS-1) with reference value of mercury $0.41 \mathrm{mg} \cdot \mathrm{kg}^{-1}$ was used to control the correctness of the analytical procedure.

After determining the mercury content in the studied soils, statistical analysis was performed to check if there was a correlation between the soil properties and mercury content. All statistical calculations were performed using Statistica 6.0 software (StatSoft, Inc 2001).

\section{RESULTS AND DISCUSSION}

The results of the analysis pertaining to the granulometric composition of the tested soil samples did not differ significantly. According to the soil standards of the Polish Soil Society, the dominant mechanical groups were sandy loam and loamy sand (Table 1). According to Gworek et al. (2011), in sandy loams, the leaching of mercury

Table 1. Granulometric composition of studied fractions (\%)

\begin{tabular}{|c|c|c|c|c|c|c|c|c|c|c|}
\hline \multirow{2}{*}{$\begin{array}{c}\text { Sample } \\
\text { no. }\end{array}$} & \multicolumn{9}{|c|}{ Granulometric fractions diameter in millimeters [\%] } & Mechanical \\
\hline & $2-1$ & $1-0.5$ & $0.5-0.25$ & $0.25-0.1$ & $0.1-0.05$ & $0.05-0.02$ & $0.02-0.006$ & $0.006-0.002$ & $<0.002$ & group \\
\hline 1 & 2.3 & 4.5 & 32.3 & 28.9 & 4 & 11 & 4 & 6 & 7 & sandy loam \\
\hline 2 & 1.9 & 17.5 & 46.5 & 19.1 & 4 & 2 & 3 & 4 & 2 & loamy sand \\
\hline 3 & 2.3 & 17.8 & 37.8 & 22.1 & 6 & 5 & 3 & 3 & 3 & loamy sand \\
\hline 4 & 1.1 & 12.8 & 46.3 & 24.8 & 3 & 4 & 2 & 2 & 4 & loamy sand \\
\hline 5 & 3.7 & 7.5 & 16.5 & 26.3 & 10 & 18 & 7 & 5 & 6 & clay \\
\hline 6 & 2.4 & 19.0 & 37.0 & 20.6 & 4 & 7 & 4 & 2 & 4 & sandy loam \\
\hline 7 & 1.6 & 16.5 & 20.0 & 18.9 & 15 & 11 & 4 & 4 & 9 & light clay \\
\hline 8 & 2.6 & 8.0 & 18.3 & 29.1 & 12 & 14 & 6 & 2 & 8 & light clay \\
\hline 9 & 1.1 & 6.3 & 18.0 & 30.6 & 10 & 13 & 9 & 4 & 8 & medium clay \\
\hline 10 & 1.7 & 12.3 & 29.3 & 24.7 & 10 & 10 & 5 & 4 & 3 & sandy loam \\
\hline 11 & 1.6 & 11.5 & 22.3 & 26.6 & 9 & 18 & 3 & 3 & 5 & light clay \\
\hline 12 & 0.1 & 5.3 & 15.8 & 27.8 & 11 & 20 & 9 & 7 & 4 & clay \\
\hline 13 & 1.3 & 8.3 & 43.0 & 33.4 & 3 & 5 & 2 & 2 & 2 & sandy loam \\
\hline
\end{tabular}


and its compounds to the deeper soil layers occurs faster, which may result in a decrease of the mercury concentration in the surface layer. The results of physicochemical properties of the studied soils are included in Table 2.

The $\mathrm{pH}$ tests of the collected soil samples showed that in both Ursynów and Mokotów, neutral and alkaline soils were dominant. Literature sources indicate that "alkalinization of soils may be associated with the lumpy nature of anthropogenic embankment layers, which contain fragments of carbonate mortar that neutralizes the natural acidification of soils and acidification of precipitation with alkaline dust emitted by municipal power plants" (Dusza-Dobek, 2012).

For comparison, soil tests were carried out in the Solska Forest, where the reaction of the tested soils was neutral.

Increased $\mathrm{pH}$ values determined in the samples in Warsaw correspond with the low values of hydrolytic acidity, which had a value of $15.15 \mathrm{cmol}(+) \cdot \mathrm{kg}^{-1}$ only in one sample, while in the other samples it was low and ranged from 1.88 to $6.60 \mathrm{cmol}(+) \cdot \mathrm{kg}^{-1}$.

The measurement of the sum of basic exchangeable cations (S) showed a large variation in the results obtained, both in Ursynów $\left(1.02-29.3 \mathrm{cmol}(+) \cdot \mathrm{kg}^{-1}\right)$ and Mokotów (4.30-46.82 $\left.\mathrm{cmol}(+) \cdot \mathrm{kg}^{-1}\right)$.

Suchalarge differencein the value of hydrolytic acidity and the sum of basic exchangeable cations influenced the differentiation of the total sorption capacity of the investigated soils in both districts.
The soil sorption capacity studies in the Solska Forest compared to the soils from Warsaw showed a lower average value of sorption capacity $\left(12.28 \mathrm{cmol}(+) \cdot \mathrm{kg}^{-1}\right)$ with a predominance of alkaline ions $\left(8.60 \mathrm{cmol}(+) \cdot \mathrm{kg}^{-1}\right)$ over acid ions $\left(3.68 \mathrm{cmol}(+) \cdot \mathrm{kg}^{-1}\right)$.

The content of organic matter was also determined in the tested soil samples. The analysis conducted in the Ursynów soils showed a significant variation in results, which ranged from $3.0 \%$ to $14.0 \%$. The Mokotów soils, with the exception of one sample (26.0\%), were characterized by a slight variation ranging from 6.0 to $7.0 \%$.

The soils studied are mineral soils in which the varied content of organic matter may result from strong anthropogenic transformations. The research conducted by Różański and DąbkowskaNaskręt (2011) shows that the content of organic matter in urban soils is strongly influenced by opencasting operations, which are constantly being carried out during urban development and development. The research carried out in the Solska Forest showed an organic content of $6.0 \%$.

In all analyzed samples, regardless of the sampling location, the value of electrical conductivity (EC) showed slight differentiation and was very low $\left(0.48-0.71 \mathrm{mS} \cdot \mathrm{cm}^{-1}\right)$. The determined values did not exceed the EC value characteristic for unsalted soils, $<4.0 \mathrm{mS} \cdot \mathrm{cm}^{-1}$. These values are characteristic of natural values, which in our latitudes range from below $1.0 \mathrm{mS} \cdot \mathrm{cm}^{-1}$ in sandy soils to about $2.0 \mathrm{mS} \cdot \mathrm{cm}^{-1}$ in the soils with heavier granulometric composition. The obtained

Table 2. Physical-chemical properties and total $\mathrm{Hg}$ content of soil samples

\begin{tabular}{|c|c|c|c|c|c|c|c|}
\hline \multirow{2}{*}{ Sample no. } & $\mathrm{pH}$ & $\mathrm{Hh}$ & $S$ & CEC & \multirow{2}{*}{$\frac{\mathrm{EC}}{\left[\mathrm{mS} \cdot \mathrm{cm}^{-1}\right]}$} & \multirow{2}{*}{$\begin{array}{l}\text { OM } \\
{[\%]}\end{array}$} & \multirow{2}{*}{$\frac{\mathrm{Hg}}{\left[\mathrm{mg} \cdot \mathrm{kg}^{-1}\right]}$} \\
\hline & $\mathrm{KCl}$ & \multicolumn{3}{|c|}{$\left[\mathrm{cmol}(+) \cdot \mathrm{kg}^{-1}\right]$} & & & \\
\hline 1 & 6.76 & 4.05 & 29.3 & 33.35 & 0.68 & 14.0 & 0.0334 \\
\hline 2 & 6.98 & 2.28 & 1.02 & 3.30 & 0.55 & 3.0 & 0.1909 \\
\hline 3 & 7.03 & 2.32 & 16.09 & 18.41 & 0.71 & 7.0 & 0.2935 \\
\hline 4 & 6.01 & 2.10 & 4.58 & 6.68 & 0.62 & 5.0 & 0.3196 \\
\hline 5 & 6.85 & 2.92 & 18.66 & 21.58 & 0.55 & 13.0 & 0.0665 \\
\hline 6 & 5.43 & 3.78 & 8.43 & 12.21 & 0.52 & 5.0 & 0.4004 \\
\hline 7 & 6.85 & 2.55 & 14.95 & 17.50 & 0.66 & 6.0 & 0.2320 \\
\hline 8 & 7.03 & 2.25 & 26.75 & 29.0 & 0.53 & 6.0 & 0.3662 \\
\hline 9 & 7.12 & 1.88 & 46.82 & 48.70 & 0.54 & 7.0 & 0.4011 \\
\hline 10 & 6.12 & 3.45 & 10.34 & 13.79 & 0.57 & 7.0 & 0.2553 \\
\hline 11 & 3.85 & 15.15 & 9.04 & 24.19 & 0.48 & 26.0 & 0.4213 \\
\hline 12 & 4.42 & 6.60 & 4.30 & 10.90 & 0.63 & 6.0 & 1.3098 \\
\hline 13 & 6.85 & 3.68 & 8.60 & 12.28 & 0.57 & 6.0 & 0.2544 \\
\hline
\end{tabular}

$\mathrm{H}$ - hydrolytic acidity; S - sum of exchangeable cations; CEC - cation exchange capacity; OM - organic matter content. EC - electrical conductivity 
results do not exceed the threshold of harmfulness of salinity for plants (Sitarski, 2008).

The mercury content in the analyzed soil samples taken from the area of Warsaw ranged from $0.0334 \mathrm{mg} \cdot \mathrm{kg}^{-1}$ to $0.4004 \mathrm{mg} \cdot \mathrm{kg}^{-1}$ in Ursynów, while the soils from the Mokotów area contained from $0.2320 \mathrm{mg} \cdot \mathrm{kg}^{-1}$ to $1.3098 \mathrm{mg} \cdot \mathrm{kg}^{-1}$. For comparison, the sample from the Solska Forest area contained $0.2544 \mathrm{mg} \mathrm{Hg} \cdot \mathrm{kg}^{-1}$.

The obtained results are comparable with the research presented by Gworek et al. (2011), in which the authors determined the total mercury content at the level of 0.001 to $0.237 \mathrm{mg} \cdot \mathrm{kg}^{-1}$ regardless of their soil location and distance from the roadway.

While comparing the obtained mercury content in the analyzed soils to the currently binding Regulation of the Minister of the Environment of 1 September 2016 on the method of conducting soil surface pollution assessment (Journal of Laws of 1 September 2016, item 1395), it should be noted that the mercury content did not exceed the proposed threshold for mercury in soil.

After determining the mercury content in the studied soils, a statistical analysis was carried out, which showed that there is a statistically significant correlation only between the soil $\mathrm{pH}$ and the content of this element in the soil (Fig. 1).

The significant effect of $\mathrm{pH}$ on the mercury content in soil is also confirmed by the studies of Rożański and Dąbkowska-Naskręt (2011).
The authors indicate that the main absorbent of mercury in acid soils is organic matter, whereas in slightly alkaline or neutral soils, clay minerals and iron, manganese and alumina have higher sorption properties.

\section{CONCLUSIONS}

The results of the analysis pertaining to the granulometric composition of the tested soil samples did not differ significantly. The dominant mechanical groups were sandy loam and loamy sand. The tested soils differed in the soil cation exchange capacity $(\mathrm{T})$ with a significant advantage of the sum of basic exchangeable cations (S). The analysis of the organic matter (OM) content in the soils of Ursynów and Mokotów showed a wide diversity, which may be due to strong anthropogenic transformations. This may result in the accumulation of mercury in the surface layers of the studied soils and may be a potential source of mercury reemission to other environmental compartments.

The total concentration of mercury determined in the studied soils varied from 0.0334 to $1.3098 \mathrm{mg} \cdot \mathrm{kg}^{-1} \mathrm{dm}$ allows to treat that studied soils as unpolluted, according to the Polish regulation. Although the results do not indicate mercury pollution, taking into account the toxic effects of this element on animals, plants and

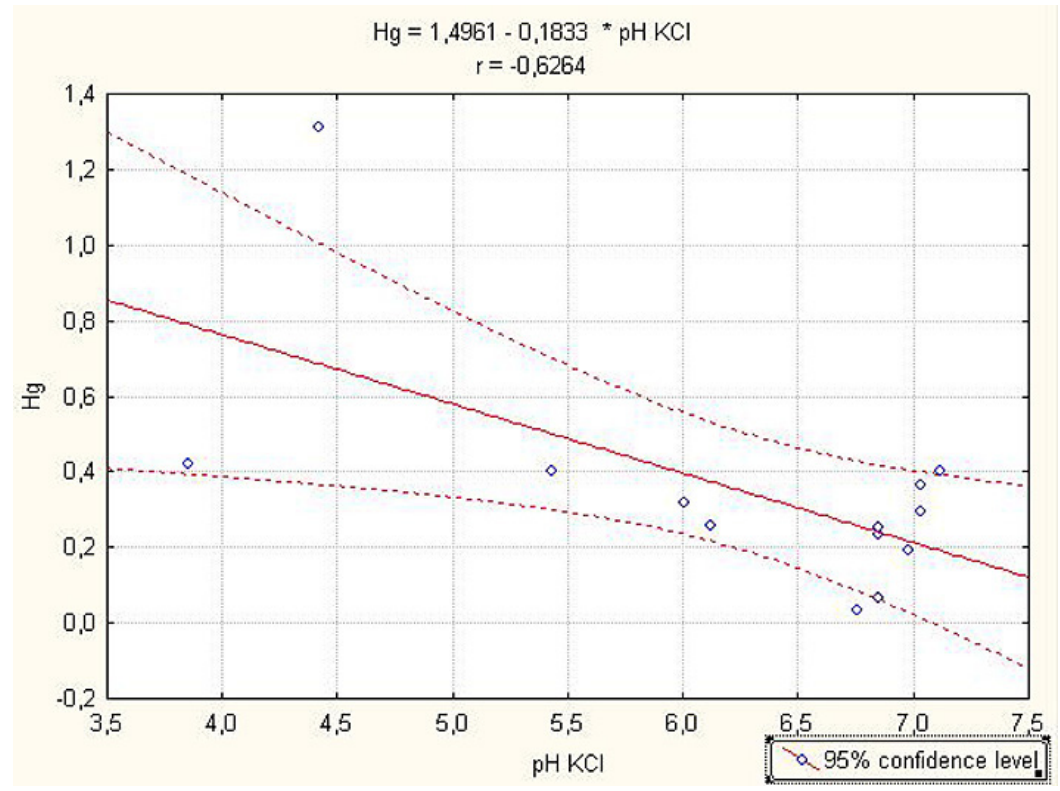

Fig. 1. Correlation between the soil $\mathrm{pH}$ and the mercury content in the soil 
humans, it is necessary to monitor mercury levels in soil to reduce the potential risk of soil recontamination with this element.

\section{REFERENCES}

1. Bartkowiak A., Jaworska H., Różański Sz. 2013. Ocena zawartości rtęci w poziomach powierzchniowych i podpowierzchniowych intensywnie użytkowanych rolniczo gleb aluwialnych, Soil Science Annual, 64 (1/2), 49-53

2. Dusza-Dobek A., 2012. Badania geochemiczne gleb w wybranych parkach Warszawy, Biuletyn Państwowego Instytutu Geologicznego 450, 35- 46

3. Gworek B., Dąbrowski P., Poniecka B., Wrzosek J., 2011. Impact of road traffic on the soils and plants contamination, Przem. Chem., 89/7, 267-271 (in Polish).

4. Hammond C.R., 2005. The Elements in Lide, CRC Handbook of Chemistry and Physics, Boca Raton, CRC Press,

5. Journal of Laws item 1395 of 1 September 2016.
Regulation of the Minister of the Environment of 1 September 2016 on the method of conducting soil surface pollution assessment.

6. Małuszyńska I., Popenda A., Małuszyński M.J., 2011. Mercury in the environment, Environ. Prot. Nat. Resour., 49, 484-493.

7. Ostrowska A., Gawliński S., Szczybiała Z., 1991. Methods of Analyses and Estimation of Soils and Plants Properties - Catalogue, IOŚ, Warsaw (in Polish).

8. Rożański S., Dąbkowska- Naskręt H., 2011. Przestrzenne i profilowe rozmieszczenie rtęci w urbanoziemiach miasta Bydgoszcz, Ochrona Środowiska i Zasobów Naturalnych nr 49, 193-201

9. Sitarski M., 2008. Charakterystyka warunków glebowych i szaty roślinnej w wybranych osiedlach mieszkaniowych Warszawy. Człowiek i środowisko 32 (1-2), 19-41

10. StatSoft, Inc 2001 STATISTICA 6.0 PL - data analysis software (in Polish).

11. Xu J., A.G. Bravo, A. Lagerkvist, S. Bertilsson, R. Sjöblom, J. Kumpiene, 2015. Sources and remediation techniques for mercury contaminated soil. Environ. Int., 74, 42-53. 